\title{
Recipients of 2020 AJCC Most Influential Paper Award
}

\section{AJCC Editorial Board}

How to cite this paper: AJCC Editorial Board (2020). Recipients of 2020 AJCC Most Influential Paper Award. American Journal of Climate Change, 9, 355-356. https://doi.org/10.4236/ajcc.2020.94021

Received: July 28, 2020

Accepted: November 20, 2020

Published: November 23, 2020

Copyright $\odot 2020$ by author(s) and Scientific Research Publishing Inc. This work is licensed under the Creative Commons Attribution International License (CC BY 4.0).

http://creativecommons.org/licenses/by/4.0/

\begin{abstract}
The AJCC Most Influential Paper Award recognizes papers that had significant impacts in the scientific community (e.g. cited by Nature, Science) or had more than 15 citations based on the Web of knowledge.
\end{abstract}

\section{Keywords}

AJCC Most Influential Paper Award

Each year, the editorial board of American Journal of Climate Change (AJCC) reviews the papers published by AJCC to select the papers they consider to have had the most influence on the research of climate change and related fields since their original publication. The AJCC Most Influential Paper Award recognizes papers that had significant impacts in the scientific community (e.g. cited by Nature, Science) or had more than 15 citations based on the Web of knowledge. This award consists of a certificate listing the paper, the author's name and the author's affiliation and carries a financial prize of $\$ 599$ to cover the article processing charge of their future paper published by AJCC.

\section{Recipients of 2020 AJCC Most Influential Paper Award Are}

The following articles had more than 15 citations based on the Web of knowledge.

Mbaye, M., Hagemann, S., Haensler, A., Stacke, T., Gaye, A. and Afouda, A., "Assessment of Climate Change Impact on Water Resources in the Upper Senegal Basin (West Africa)", American Journal of Climate Change, Vol. 4 No. 1, 2015, pp. 77-93. doi: 10.4236/ajcc.2015.41008.

Chou, S., Lyra, A., Mourão, C., Dereczynski, C., Pilotto, I., Gomes, J., Bustamante, J., Tavares, P., Silva, A., Rodrigues, D., Campos, D., Chagas, D., Sueiro, G., Siqueira, G., Nobre, P. and Marengo, J. "Evaluation of the Eta Simulations Nested in Three Global Climate Models", American Journal of Climate Change, Vol. 3 No. 5, 2014, pp. 438-454. doi: 10.4236/ajcc.2014.35039. 
Mondal, M., Jalal, M., Khan, M., Kumar, U., Rahman, R. and Huq, H., "Hydro-Meteorological Trends in Southwest Coastal Bangladesh: Perspectives of Climate Change and Human Interventions", American Journal of Climate Change, Vol. 2 No. 1, 2013, pp. 62-70. doi: 10.4236/ajcc.2013.21007.

I. Cavalcanti and M. Shimizu, "Climate Fields over South America and Variability of SACZ and PSA in HadGEM2-ES", American Journal of Climate Change, Vol. 1 No. 3, 2012, pp. 132-144. doi: 10.4236/ajcc.2012.13011. 